\title{
The Intersection of Behavioral Genetics and Political Science: Introduction to the Special Issue
}

\author{
Peter K. Hatemi ${ }^{1,2}$ \\ ${ }^{1}$ Political Science, Microbiology and Biochemistry, The Pennsylvania State University, USA \\ ${ }^{2}$ United States Studies Centre, University of Sydney, Australia
}

\begin{abstract}
The collection of papers in this special edition of Twin Research and Human Genetics represents a major landmark at the intersection of behavioral genetics and political science. This issue is the fruit of 20 political scientists attending the Behavioral Genetics Association Methods Workshop in Boulder and a hands-on training practicum at the Virginia Institute for Psychiatric and Behavioral Genetics, and includes results from the first wave of political science twin surveys.
\end{abstract}

- Keywords: politics, attitudes, ideology, trust, participation

The genetic influence on social and political attitudes was first introduced by Lindon Eaves, Hans Eysenck, and Nicholas Martin (Eaves \& Eysenck, 1974; Eaves, Eysenck, \& Martin, 1989; Martin et al., 1986). Several decades later, the greater social science community engaged these findings, and the discipline of political science has begun in earnest to explore genetic influences on political traits, extending far beyond their predecessors.

The history of how social and political attitudes became a topic of genetic exploration, and why Lindon Eaves, his postdoctoral supervisor, Hans Eysenck, and his first PhD student, Nicholas Martin, began the first explorations on the genetics of social attitudes was fortuitous. Although not uncommon for a psychologist to study social attitudes, for two geneticists, it was slightly out of the norm. Yet, all three scholars had a personal interest in social and political attitudes; but the inclusion of social attitudes for exploration in a twin design was not only chosen because of scholarly interest. Rather, attitudes were also included to validate the twin model. That is, they sought to find a trait that was certainly 'not genetic' for comparison to other traits that might be genetically influenced. Such a view seemed reasonable, as the prevailing view in the social sciences, epitomized by Emile Durkheim, (1895 [1964], p. 110), was that 'The determining cause of a social fact should be sought among the social facts preceding it and not among the states of individual consciousness'. Social attitudes were believed to be no exception; that is, until such views could no longer withstand the mounting empirical evidence that Eaves, Eysenck, and Martin produced.

Indeed, today, Martin et al. (1986), is considered the seminal piece in the genetics and sociopolitical attitudes literature. The 'Transmission of Social Attitudes' relied on over 4500 Australian and British twin pairs, and assessed 50 attitudes. They found a high degree of assortative mating on attitudes, and little evidence of vertical cultural inheritance; a genetic model for family resemblance was required to explain individual differences in social attitudes. That is, 'social facts' accounted for very little variance in attitudes and, rather, one's genetically informed psychological disposition and personal experiences explained why individuals differ in their attitudes. The finding was a direct challenge to centuries of belief on attitudes. Several papers and books from these scholars followed, expanding upon their initial findings through larger US and Australian samples and utilizing extended kinship models, which took into account assortative mating and gene-environment covariance, among other factors (Eaves, Eysenck, \& Martin, 1989; Eaves et al., 1999; Posner, Baker, Heath, \& Martin, 1996). Eaves and Martin's

\section{RECEIVED 17 October; ACCEPTED 01 December, 2011}

ADDRESS For CORRESPONDENCE: Peter Hatemi, 307 Pond Lab, University Park, State College, PA 16803, USA. Email: phatemi@gmail.com 
contemporaries in psychology took notice and began using the alternative twins reared apart design. Tom Bouchard and Matthew McGue relied on over a 100 pairs of identical twins reared apart, and produced strikingly similar findings to the twin-reared-together studies (Bouchard, Lykken, McGue, Segal, \& Tellegen, 1990, Bouchard \& McGue, 2003). These studies resulted in psychologists' placing attitudes on a par with personality with regard to familial transmission.

Yet, any discussion of genetic influence remained absent in the discipline of political science, the field in which the study of attitudes is a central theme (for an exception see Madsen, 1986). That is, until 2005, when several groups of political scientists began to show an interest in this area. The first paper published was by John Hibbing and John Alford, who contacted Dr Eaves for access to his data through their colleague, Cary Funk, who was at the same institution as Dr Eaves. As result of this meeting, in 2005, Alford, Funk and Hibbing published a landmark piece in the American Political Science Review. The article relied on the same data and correlations provided by Eaves (Eaves et al., 1989, 1999), but recast them toward a political science audience. For decades, the Eaves and Martin discoveries lay dormant, but once introduced directly into the political science literature, it launched an awakening in the social sciences, and an unprecedented move toward the inclusion of dispositional traits in the study of social and political phenomena. Since 2005, over 40 publications by political scientists that utilize behavior genetics models and data to explore political phenomena have been published in the highest impact political science journals. These studies have begun to integrate the theoretical, conceptual, and methodological approaches of behavioral genetics and political science (for a review, see Hatemi, Dawes et al., 2011). Studies included: identifying the heritability of voter turnout (Fowler, Baker, \& Dawes, 2008); exploring common genetic influence on attitudes and vote choice using multivariate twin models (Hatemi, Medland, Morley, Heath, \& Martin, 2007); utilizing extended kinships and assortative mating to identify special twin environments and passive gene-environment covariation (Eaves \& Hatemi, 2008; Hatemi et al., 2010); conducting longitudinal twin studies (from children to adulthood) on attitudes (Hatemi, Funk, et al., 2009); exploring the covariance between personality, partisanship, and intensity (Hatemi, Alford, Hibbing, Martin, \& Eaves, 2009; Settle, Dawes, Christakis, \& Fowler, 2010; Verhulst, Hatemi \& Martin, 2010; Verhulst, Eaves, \& Hatemi, 2012); normative implications of genetics (Hatemi \& McDermott, 2011b); gene-environment interplay on political violence (Hatemi \& McDermott, in press); the difference between sex and gender and its impact on vote choice and attitudes (Hatemi, Medland, \& Eaves, 2009; McDermott \& Hatemi, 2011); candidate gene relationships between dopamine, monoamine oxidase and catechol-o-methyltransferase, and voter turnout (Dawes \& Fowler, 2009; Fowler \& Dawes, 2008); and genome-wide analyses on attitudes (Hatemi et al., 2011). By 2011, it was clear that genetics could no longer be ignored in mainstream political science. This research coincided with the inclusion of a wide array of neurobiological approaches such as neuroscience (Fowler \& Schreiber, 2008), physiology (Oxley et al., 2010), and endocrinology (McDermott, Tingley, Cowden, Frazzetto, \& Johnson, 2009), which signaled that the discipline was undergoing a major change.

However, only a handful of political scientists remained responsible for nearly all the research that integrated behavioral genetics and political science. They were: John Hibbing, John Alford and Kevin Smith working out of the University of Nebraska and Rice University; Pete Hatemi, a product of both Nick Martin's Genetic Epidemiology Unit and Lindon Eaves' and Michael Neale's research team at the Virginia Institute for Psychiatric and Behavioral Genetics ; and James Fowler and Chris Dawes in the Department of Political Science at the University of California, San Diego. These groups were not at all distinct, in that they often interacted and sometimes worked together. At one such meeting in 2008, financially supported by Michael Gazzaniga, Rose McDermott and Pete Hatemi brought together these scholars and their students to consider ways to move the larger research agenda forward and make it more inclusive to the greater political science community. The meeting attendees included Jason Boardman, Chris Dawes, Lindon Eaves, James Fowler, Pete Hatemi, John Hibbing, Rose McDermott, Sarah Medland, Darren Schreiber, Kevin Smith, Political Science, Alan Stam, and Tim Johnson.

Two important, but intertwined, challenges emerged from this meeting. The first was that it was necessary to generate new twin data, specific to political science, freely available to the discipline. There was a significant amount of criticism directed toward the data used in the extant literature. The large twin studies conducted by Nick Martin and Lindon Eaves, which were the foundation for most of the publications in this area, relied upon attitudinal and voting measures that were not the standard measures common to political science. Moreover, the data were collected in the 1980s and 1990s. Thus, the age of the data and question wording became points of contention. Furthermore, most twin data are linked to large registries and part of ongoing and active studies, and are not publically available, making it difficult for new entrants to engage this area of research.

The second challenge was accessibility. The majority of political scientists have no training in biology or genetics, and science courses are typically not required for undergraduate or graduate programs in political science. In addition, the methodological techniques utilized in behavioral genetics are uncommon in political science; there was a specific need to train those who want to conduct 
TABLE 1

Summary of Traits Assessed in Three New Twin Studies on Politics

\begin{tabular}{|c|c|c|c|}
\hline & $\begin{array}{c}\text { Denmark } 2009 \\
\text { Wave } 1\end{array}$ & US 2008 & $\begin{array}{c}\text { Australia } 2008 \\
\text { Wave } 1\end{array}$ \\
\hline \multicolumn{4}{|l|}{ Sample Characteristics } \\
\hline Web & 3616 & 1190 & 574 \\
\hline Paper & 0 & 240 & 2 \\
\hline Phone & 0 & 0 & 0 \\
\hline MZM Pairs & 157 & 143 & 36 \\
\hline DZM Pairs & 132 & 86 & 29 \\
\hline MZF Pairs & 283 & 213 & 61 \\
\hline DZF Pairs & 243 & 154 & 55 \\
\hline DZUS Pairs & 261 & 0 & 70 \\
\hline \multicolumn{4}{|l|}{ Single twins } \\
\hline (missing cotwin) & 0 & 157 & 74 \\
\hline Other Kinships & 0 & 0 & $\begin{array}{c}\text { Planned } \\
\text { for Wave } 2\end{array}$ \\
\hline Total & 3616 & 1430 & 576 \\
\hline Assessed During Election & $\mathrm{N}$ & Y & $Y$ \\
\hline \multicolumn{4}{|l|}{ Sample Demographics } \\
\hline Age (mean/Std) & $29.3 / 6.1$ & $56.0 / 2.5$ & $26.0 / 3.1$ \\
\hline$\%$ Males/Females & $41.3 / 59.7$ & $36.3 / 62.7$ & $42.0 / 58.0$ \\
\hline \multicolumn{4}{|l|}{ Education } \\
\hline Less than high School & 22.71 & 1.7 & 2.3 \\
\hline High School & 11.95 & 15.0 & 20.8 \\
\hline Technical School & 19.41 & 21.5 & 20.1 \\
\hline Some College & Not offered & 23.1 & 15.9 \\
\hline 4 yr. Degree & 45.93 & 21.2 & 29.8 \\
\hline Adv. Degree & Not offered & 17.0 & 11.1 \\
\hline Other & Not offered & .5 & Not offered \\
\hline \multicolumn{4}{|l|}{ Religion } \\
\hline Protestant & 82.6 & 44.3 & 9.0 \\
\hline Catholic & .6 & 35.5 & 33.1 \\
\hline Jewish & .17 & .8 & .2 \\
\hline Muslim & .17 & Not offered & 24.4 \\
\hline Other & 1.43 & 13.9 & 16.1 \\
\hline None & 15.02 & 5.4 & Not offered \\
\hline Agnostic & Not offered & Not offered & 9.5 \\
\hline Atheist & Not offered & Not offered & 7.6 \\
\hline prefer not to answer & 0 & 0 & 0 \\
\hline \multicolumn{4}{|l|}{ Measures } \\
\hline \multicolumn{4}{|l|}{ Authoritarianism/ } \\
\hline Life Values & $\mathrm{Y}$ & Y & Y \\
\hline Conflict avoidance & Planned for Wave 2 & $\mathrm{~N}$ & $Y$ \\
\hline Disgust & $\mathrm{N}$ & $\mathrm{N}$ & Y \\
\hline Economic choices & Y & $Y$ & Y \\
\hline Efficacy & $\mathrm{Y}$ & $Y$ & Y \\
\hline Emotion reading & Planned for Wave 2 & $\mathrm{~N}$ & Y \\
\hline Equality/Fairness & Y & Y & Y \\
\hline Experiments & Welfare vignettes & Economic & $\begin{array}{c}\text { Economic } \\
\text { (real money) }\end{array}$ \\
\hline Government approval & Y & Y & Y \\
\hline Issue Importance & Y & Y & Y \\
\hline Machiavellian & $\mathrm{N}$ & $\mathrm{N}$ & Y \\
\hline Morality & Planned for Wave 2 & $Y$ & Y \\
\hline Participation & Y & Y & Y \\
\hline Partisanship & Planned for Wave 2 & Y & Y \\
\hline Five Factor Personality & Planned for Wave 2 & Y & Y \\
\hline Political Attitudes & $\mathrm{Y}$ & Y & Y \\
\hline Political Knowledge & $Y$ & $Y$ & Y \\
\hline Political Trust & Y & Y & Y \\
\hline Political Interest & Y & Y & $Y$ \\
\hline Pro-Sociality & $Y$ & Y & $Y$ \\
\hline Religiosity/spirituality & $\mathrm{Y}$ & Y & Y \\
\hline Risk aversion & Planned for Wave 2 & Y & Y \\
\hline Self Report Ideology & Planned for Wave 2 & Y & Y \\
\hline Twin Contact & $Y$ & $Y$ & Y \\
\hline Vote Choice & $\mathrm{N}$ & $Y$ & $Y$ \\
\hline Vote turnout & Y & Y & Y \\
\hline \multicolumn{4}{|l|}{ Socio-demographics } \\
\hline (income, occupation, etc. & Y & Y & Y \\
\hline
\end{tabular}

primary research in this area, as well as to create informed consumers.

The core group of scholars at this meeting undertook three tasks to meet these challenges. The first was to contribute to an edited volume, now published (Hatemi \& McDermott, 2011a), which guided the unfamiliar political scientist through evolution to heritability, gene-environment interaction, candidate genes, hormones, and the neuroanatomy of political behavior. The volume provides both the theoretical and methodological tools necessary for interested scholars to directly engage in this area of research.

The second endeavor was to provide data to those in political science who wanted to conduct primary research in this area. Some of this work occurred previous to the meeting; the National Science Foundation funded a data collection project to produce an abbreviated national election studies twin data set for the 2008 election (0721378, PI: Hibbing, Alford, Funk, Hatemi, \& Smith). This data is publically available at www.unl.edu/polphyslab. At the same time, several other political twin data collection projects began. Robert Klemmensen and Asbjørn Sonne Nørgaard at Syddansk Universitet launched the first Danish twin political study. In addition, Alford, Hatemi, Hibbing, Smith, \& Martin (0721707) began a multiplewave study of economic, emotional, and political behavior in Australia. Table 1 provides a summary of the measures collected and sample sizes of these recent studies.

This combination of data should provide unparalleled insight into the sources of individual differences on political traits. Measures include voting, nonvoting participation, efficacy, trust, interest, knowledge, emotion, rationality, personality, familial influence, attitudes, religiosity, and morality, among many others. The measures were taken from general social science surveys and country-specific surveys such as the American National Elections Studies, as well as those that generalize across countries, such as the World Values Survey. Other measures include standardized personality scales and well-known instruments for emotion reading. Through these data collection efforts, the papers in this issue address questions on direction of causality, genetic and environmental covariance, and unequal environments, among others.

The third effort revolved around providing specific instruction to those wanting to conduct this kind of research, but who lacked training. As a response, the National Science Foundation funded political scientists (0921008, PI: Hatemi) to attend the 2010 International Workshop on Statistical Genetics and Methodology of Twin and Family Studies at Boulder, and to take part in a follow-up, hands-on workshop at the Virginia Institute for Psychiatric and Behavioral Genetics (1047687, PI: Hatemi), in which students brought their own data and designs to work with faculty to produce publishable papers. 
This issue is the fruit of those political scientists who attended the two workshops. The issue includes eight empirical studies on topics of central importance to political science. Indeed, the foundation of a democratic society rests on trust in the political system, efficacy, being informed of policy and governmental decisions, and, most of all, political participation.

We begin with Levente Littvay's empirical test of the equal environments assumption with regard to political attitudes. A great deal of criticism has been levied against twin studies regarding the potential for unequal environmental influence by zygosity type, specifically with regard to political attitudes.

We follow with Robert Klemmensen and colleagues' comparison of genetic and environmental sources of variance in political interest across two very different Western political cultures, Denmark and the USA. Sven Oskarsson and colleagues' exploration of the heritability of social trust and its relationship to other personality traits in a large Swedish twin sample follows. These studies address one of the major shortcomings in the genetics and politics literature. That is, past studies of genetic influences on political traits have so far relied on two very similar populations, with similar political institutions and cultural climates, the USA and Australia. These two papers examine if genetic influences on political traits markedly differ in varied political and cultural contexts such as social welfare states, namely Sweden and Denmark.

The next set of papers focuses on the source of the relationship between predictors and political traits. Kevin Arceneaux, Martin Johnson and Hermine Maes explore the potential for a common genetic influence on variation in educational attainment, political interest, and political knowledge. Brad Verhulst takes the core predictors of political participation in the social science literature and explores the source of the covariance between the predictors and participation.

The issue follows with two studies by Skyler Cranmer and Christopher Dawes; and Allan Stam, Alexander Von HagenJamar, and Alton Worthington, which focus on foreign policy attitudes and their relationship to ideology and the perception of the world as a dangerous place. The final empirical paper by D'andra Orey provides an exploration of social and genetic influences on ethnocentric attitudes. We close with a detailed study description of the Danish political twin study, which is compared to a random Gallup study taken at the same time.

For many of these scholars, this is the first time they have conducted behavioral genetic analyses, and this issue represents, at long last, the beginning of the conversation between political science and genetics.

\section{Acknowledgments}

This issue, and all the things leading up to it, including my current career, could never have been accomplished without the wisdom, vision, guidance, support, and friendship of my mentors and friends, Nicholas Martin and Lindon Eaves. I would also like to thank Rose McDermott, whose friendship, hard work, and support have led to this issue. I thank Sarah Medland for her dedication to methodological rigor, her instruction and most of all her friendship. I thank Michael Gazzaniga for funding our first conference, and Brian Humes at the National Science Foundation for taking a chance on our project (grants 0721378; 0921008; 1047687). I also thank John Hewitt for working with us to train political scientists in behavior genetics, and all the instructors at the 2010 International Workshop on Statistical Genetics and Methodology of Twin and Family Studies. And finally, I would like to express my personal gratitude to Michael Neale, Hermine Maes, Matthew Keller, Elizabeth PromWormley, Nathan Gillespie, Brad Verhulst, Chris Dawes, and Levente Littvay for volunteering their time as instructors in the hands-on training; their efforts are reflected in each of these manuscripts.

\section{References}

Alford, J. C., Funk, C. L. \& Hibbing, J. (2005). Are political orientations genetically transmitted? The American Political Science Review, 99,153-167.

Bouchard, T. J., Jr., Lykken, D. T., McGue, M., Segal, N. L., \& Tellegen, A. (1990). Sources of human psychological differences: The Minnesota study of twins reared apart. Science, 250, 223-228.

Bouchard, T. J. Jr., \& McGue M. (2003). Genetic and environmental influences on human psychological differences. Journal of Neurobiology, 54, 4-45.

Durkheim E. (1895 [1964]). The rules of sociological methods. London: Free Press

Dawes, C. T., \& Fowler, J. H. (2009). Partisanship, voting, and the dopamine D2 receptor gene. Journal of Politics, 71, 1157-1171.

Eaves, L. J., \& Eysenck H. (1974). Genetics and the development of social attitudes. Nature, 249, 288-289.

Eaves, L. J., Eysenck, H. J., \& Martin, N. G. (1989). Genes, culture and personality: An empirical approach. London: Academic Press.

Eaves, L. J., \& Hatemi, P.K. (2008). Transmission of attitudes toward abortion and gay rights: Parental socialization or parental mate selection? Behavior Genetics, 38, 247-256.

Eaves, L. J., Heath, A., Martin, N., Maes, H., Neale, M., Kendler, K., Kirk K., \& Corey L. (1999). Comparing the biological and cultural inheritance of personality and social attitudes in the Virginia 30,000 Study of Twins and their Relatives. Twin Research and Human Genetics, 2, 6280.

Fowler, J. H., Baker, A., \& Dawes, C. T. (2008). Genetic variation in political participation. The American Political Science Review, 102, 233-248.

Fowler, J. H., \& Dawes, C. T. (2008). Two genes predict voter turnout. Journal of Politics 70:579-594. 
Fowler, J. H., \& Schreiber, D. (2008). Biology, politics, and the emerging science of human nature. Science, 322, 912.

Hatemi, P. K., Alford, J., Hibbing, J., Keller, M., Martin, N., Medland, S., \& Eaves, L. (2010). Not by twins alone: Using the extended twin family designed to investigate the genetic basis of political beliefs. American Journal of Political Science, 54, 798-814.

Hatemi, P. K., Alford, J. R., Hibbing, J. R., Martin, N. G., \& Eaves, L. J. (2009). Is there a 'party' in your genes? Political Research Quarterly, 62, 584-600.

Hatemi,P. K., Dawes, C. T., Frost-Keller, A., Settle, J., \&Verhulst, B. (2011). News from the political front: Genetics of social attitudes. Biodemography, 57, 67-87.

Hatemi, P. K., Funk, C. L., Maes, H., Silberg, J., Medland, S. E., Martin, N. G., \& Eaves, L. J. (2009). Genetic influences on political attitudes over the life course. Journal of Politics, 71(3), 1141-1156.

Hatemi, P. K., Gillespie, N. A., Eaves, L. J., Maher, B. S., Webb, B. T., Heath, A. C., Medland, S.E., Smyth, D.C., Beeby, H. N., Gordon, S.D., Montgomery, G. W., Zhu, G., Byrne, E. M., \& Martin, N. G. (2011). Genome-wide analysis of political attitudes. Journal of Politics, 73, 1-15

Hatemi, P. K., \& McDermott, R. (Eds.). (2011a). Man is by nature a political animal. Chicago: University of Chicago Press.

Hatemi P. K., \& McDermott, R. (2011b). Normative implications of biological approaches to behavior PS: Political Science and Politics, 44, 325-329.

Hatemi, P.K., \& McDermott, R. (in press). The neurobiology of political violence. Foreign Policy Analysis.

Hatemi, P. K., Medland, S. E., \& Eaves, L. J. (2009). Genetic sources for the gender gap? Journal of Politics, 71, 1-13.

Hatemi, P. K., Medland, S. E., Morley, K. I., Heath, A. C., \& Martin, N. G. (2007). The genetics of voting: An Australian twin study. Behavior Genetics, 37, 435-448.
Madsen, D. (1986). Power seekers are different: Further biochemical evidence. The American Political Science Review, 80, 261-269.

Martin, N. G., Eaves, L. J., Heath, A. C., Jardine, R., Feingold, L. M., \& Eysenck, H. J. (1986). Transmission of social attitudes. Proceedings of the National Academy of Sciences of the United States of America, A83, 4364-4368.

McDermott, R., \& Hatemi, P.K. (2011). Distinguishing sex and gender. PS: Political Science and Politics, 44(1), 89-92.

McDermott, R., Tingley, D., Cowden, J., Frazzetto, G., \& Johnson, D. P. (2009). Monoamine oxidase A gene (MAOA) predicts behavioral aggression following provocation. Proceedings of the National Academy of Sciences of the United States of America, 106, 2118-2123.

Oxley, D. R., Smith, K. B., Hibbing, M.V., Miller, J. L., Alford, J. R., Hatemi, P. K., \& Hibbing, J. R. (2008). Political attitudes are predicted by physiological traits. Science, 21, 1667-1670.

Posner, S. F., Baker, L., Heath, A., \& Martin, N. G. (1996). Social contact, social attitudes, and twin similarity. Behavior Genetics, 26, 123-133.

Settle, J., Dawes, C., Christakis, N., \& Fowler, J. (2010). DRD4 moderates a relationship between adolescent friendships and ideology. Journal of Politics, 72, 1189-1198.

Verhulst, B., Eaves, L. J. and Hatemi, P. K. (2012). Correlation not Causation: The Relationship between Personality Traits and Political Ideologies. American Journal of Political Science, 56, 34-51

Verhulst, B., Hatemi, P. K., \& Martin, N. G. (2010). The nature of the relationship between personality traits and political attitudes. Personality and Individual Differences, 49,306-316. 